\title{
DETERMINING FACTOR AND LEVEL QUALITY OF SHRIMP FEED OPTIMALLY USING TAGUCHI METHOD: THE CASE OF PT KARKA NUTRI INDUSTRI SIDOARJO, INDONESIA
}

\author{
Rochmoeljati Rr.*, Utami Isni \\ Department of Industrial Engineering, Faculty of Engineering, University of Pembangunan \\ National "Veteran" Jawa Timur, Indonesia \\ *E-mail: rochmoeljati@gmail.com
}

\begin{abstract}
PT. Karka Nutri Industri is a company engaged in manufacturing that produces shrimp feed. One of the factors that influence the success of the company in running a business is the quality of the product. The production process of shrimp feed should be controlled every 2 hours once the production process runs. In the process of Water Stability (WS) is one of the problems that exist in shrimp feed. With the existence of these problems then conducted the research determining factor and level quality of shrimp feed optimally using Taguchi method. Using 3 factors, experiments were conducted from various conditions. Determination of parameters in the hope obtained by the optimal quality of shrimp feed (Water Stability). This study aims to determine the factor and level of quality of optimal shrimp feed and provide proposed improvements to improve quality with Taguchi method. Objects taken in this research are Water Stability process based on L9 $\left(3^{3}\right)$ orthogonal array matrix with three controlled factors like factor A (Temperature / (Steam), factor B (material rotational speed (RPM), factor $C$ (strong currents limit and the minimum value amximal (Ampere). This experiment also involves noise factors for a powerful introduction to noise. The data analysis of this research uses signal-to-noise ratio (SNR) with Nominal-is-Best characteristic. Based on the analysis of the research results, it can be concluded that the proposed improvement design with the Taguchi method approach is obtained by setting the factors: Temperature (Steam) $75^{\circ}$ at A3 (level 3), Material Rotation Speed (RPM) $30 \mathrm{~Hz}$ at B1 (level 1) and strong currents limit minimum and maximum value (Ampere) of $130 \mathrm{~A}$ at C3 (level 3).
\end{abstract}

\section{KEY WORDS}

Water stability, Taguchi Method, orthogonal array, proposed improvement, minitab software.

The development of industrial world in the present era is very important in economic development in Indonesia. Various kinds of industries experienced a fairly rapid development, so as to spur the emergence of competition in the industrial world will be more stringent, so that companies with each other are required to compete well. One of the factors that influence the success of the company in running a business that is the quality of the product.

Karka Nutri Industri is a company engaged in manufacturing that produce shrimp feed. Shrimp feed production process should be controlled every 2 hours once the production process runs, but in fact Water Stability (WS) is one of the problems faced by the company. Where shrimp feed is not in accordance with the required standards.

With the existence of these problems then conducted the research of determination factor and level of quality of shrimp feed optimal with Taguchi method. Using 3 factors, experiments were conducted from various conditions. Determination of parameters with hope obtained by optimal quality of shrimp feed (Water Stability). The Taguchi method is a method used in off line quality control activities at the design stage of the production process (Soejanto, 2009). Taguchi emphasizes that the best way to improve quality is to design quality into products starting from the design stage of the product so that by robust product design against noise factor, because it produces robust performance products as well.

The use of Taguchi method in this research is expected to improve the quality of the product so as to obtain the maximum quality of shrimp feed. 


\section{LITERATURE REVIEW}

Taguchi Method. Taguchi method is a structured approach to determine the best combination in producing products in the form of goods or services. Genichi Taguchi developed a design approach from a robust design perspective, in which the product must be made defect-free and of high quality (Taguchi, et al, 2005)

Quality definition by Taguchi is the quality of a minimum loss product provided by a product to the public or consumer since the start of the product is ready to be sent to the consumer. Based on the definition, then there is a new perspective where a quality not only in the production process but also associated with the loss to the community (producers and consumers). The purpose of the Taguchi loss function (loss function) is to evaluate quantitative loss of quality caused by variations. (Belavendram, 1995) in (Ermawati, 2014).

Quality control activities (QC) are divided into two, which are:

1. Off-line QC: Off-line QC is a quality control activity conducted before the production process takes place;

2. On-line QC: On-line QC is a quality control measures after the production process.

Orthogonal Array. Orthogonal array is one of the Fractional Factorial Experiment (FFE) groups. Orthogonal array can be to evaluate several factors with a minimum number of experiments. Orthogonal array serves to design an experiment to analyze experimental data. The selection of orthogonal array must be adjusted to the number of factors and their level to be observed. The selection of orthogonal array must meet the inequalities. (Belavendram, 1995) in (Ermawati, 2014):

$$
V_{O A} \geq V_{T}
$$

That is the number of experiments - $1 \geq$ total d.o.f for all factors and their interactions. Where (Soejanto, 2009): $V_{O A}$ : number of experiments $-1 ; V_{T}$ : total number d.o.f from all factor.

Variable Response (Characteristics of Quality). Generally every quality characteristic has a target. There are 3 (three) quality characteristics grouped by target, ie (Ross, 2008):

Nominal is the best. Measuring characteristics with specific target values specified by the user (user-defined):

$$
\eta=10 \log _{10}\left(\frac{\mu^{2}}{\sigma^{2}}\right)=\frac{1}{n} \sum_{i=1}^{n} y_{i}=\frac{1}{n} \sum_{i=1}^{n}\left(y_{i}-\mu\right)^{2}
$$

Smaller is the best. Measurement of non-negative characteristic in which the target is ideally a zero:

$$
\eta=10 \log _{10}[\mathrm{MSD}]=-10 \log _{10}\left(\frac{1}{n} \sum_{i=1}^{n} y_{i}^{2}\right)=10 \log _{10}\left[\alpha^{2}+y^{2}\right]
$$

Larger is the best. Measurement of non-negative characteristics which are ideal targets infinite or $\infty$. Example:

$$
\begin{gathered}
\eta=10 \log _{10}[\mathrm{MSD}] \\
\eta=10 \log _{10}\left(\frac{1}{n} \sum_{i=1}^{n} \frac{1}{y_{1}^{2}}\right)
\end{gathered}
$$

Signal to Noise Ratio. The signal is the average value of the characteristics and displays the desired component, which is close to a predetermined target value. While noise is an undesirable component and is measured by the variability of output characteristics. Signal to noise ratio ( $\mathrm{S} / \mathrm{N}$ ratio) is a value that shows how much influence of controlled factors on the quality of the resulting product and take into account the variations of the resulting product and how close the product to the target has been determined. The $\mathrm{S} / \mathrm{N}$ ratio is used to select factors that contribute to the reduction of a factor's variation (Metasari, Nur, 2013). 
$\mathrm{S} / \mathrm{N}$ ratio calculation formula used, namely: Larger is the best. Measurement of nonnegative characteristics which are the ideal targets is infinite or $\infty$ :

$$
\begin{gathered}
\eta=10 \log _{10}[\mathrm{MSD}] \\
\eta=10 \log _{10}\left(\frac{1}{n} \sum_{i=1}^{n} \frac{1}{y_{1}^{2}}\right)
\end{gathered}
$$

Pooling Up Strategy. Pooling up strategy tend to maximize the number of columns considered significant. With significant decisions these factors will be used in the next trial round or in product or process design. Thus the tendency to make an a error (type I error) will be enlarged, namely the consideration that factors led to improvements, but does not. However, this situation is better than making a $\beta$ error (a type II error) that consideration of that factor does not lead to improvement when in fact lead to improvements.

The formula (Belavendram, 1995) in (Saputro, 2011):

$$
\begin{gathered}
S(\text { Pooled e })=S e+S D \\
V(\text { Pooled } e)=v e+v D \\
M(\text { Pooled e })=\frac{S(\text { Pooled } e)}{V(\text { Pooled })}
\end{gathered}
$$

Percent Contribution. Percent contribution is a portion of each factor and or significant interaction to the total of observed variants. Percentage of this contribution is a function of the sum of squares of each significant factor which is an indication of the strength of a factor and or factor interaction. 2011):

The formula for the percent contribution calculation (Belavendram, 1995) in (fitria,

$$
\begin{gathered}
S S_{A}^{\prime}=S S_{A}-\left(V e \times V_{A}\right) \\
P=\frac{S S_{A}}{S S_{T}} \times 100 \%
\end{gathered}
$$

Confirmation Experiment. Confirmation experiment is an experiment conducted to examine the conclusions obtained. The purpose of the confirmation experiment is to verify, among other things:

- Allegations made at the time of model determination factor and its interaction;

- Setting the parameters (factors) of the optimum analysis results of the experimental results on the perfomansi expected;

- Steps on confirmation experiment. Confirmation experiment declared successful if: there was an improvement of the existing process (after the Taguchi experiment was done); the results of the confirmation experiments close to the scores that have been researched.

\section{METHODS OF RESEARCH}

Identification and Definition of Operational Variables. In the identification of variables there are variables obtained based on data from companies used in the application of Taguchi Method along with its operational definition. The variables are as follows:

1. Free Variable. This variable is not depends on other variables. The magnitude of this variable can be determined freely depends on the desired needs. This variable consists of control factor and noise factor:

a. Water Factor;

b. Steam Factor; 
c. Rotation of machine speed factor (RPM).

2. Dependent Variable. This variable depends on the value of other variables. In this research, the dependent variable is the Quality Characteristic (Nominal is best).

Data Processing Method. The research was conducted at PT. Karka Nutri industry with the object of research on the Water Stability (WS) to optimize the quality of shrimp feed. The step of this research is doing field study and literature study. Furthermore, the formulation of the problem and determine the research objectives. The next step is conducting the data collection and processing of data obtained. After obtaining the relevant data with the problem then experimenting with orthogonal array determination and experimental data processing which includes anova, s/ $\mathrm{n}$ ratio, contribution percentage, optimal contribution determination, confidence interval then done confirmation experiment to get optimal result and proposal. The final step is to formulate conclusions and suggestions.

\section{RESULTS AND DISCUSSION}

Experiment Data. For the selection of 3 levels is the design matrix L9 (34), L27 (313), L81 (340). The degree of freedom in the orthogonal array (OA) indicates the minimum number of rows, so that the selected OA must have at least 7 rows, L9 33 being the OA matrix that can be used as an experiment.

L9 Orthogonal Array Matrix is a matrix containing 9 rows as the number of selected test combination and four columns to determine the effects of the main factors and their interactions. In this case there is only one linear form and a mapping scheme and there is only one interaction that can be combined, that the interaction of L9 (34) uses two columns instead of one column due to the degree of freedom required.

\section{3,4}

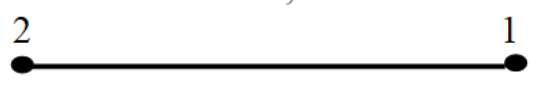

Figure 1 - Linear Graphic $L_{9}\left(3^{4}\right)$ (Soejanto, I., 2009)

Response Data Processing Each Factor Mean \& S / N Ratio. To find out the results of the calculation of process water stability through a combination of major factors, namely temperature / steam (A), Rotation Speed of Machine (RPM) (B), Strong Current (Amperes) (C) can be seen from the combination of the level and factors that optimum reached at the average value of shrimp feed on the water stability process with the greatest value of each factor, namely:

In the first experiment:

$$
\frac{\mathrm{S}}{\mathrm{N}}=-10 \log \left[\frac{1}{\mathrm{n}} \sum_{\mathrm{i}=1}^{\mathrm{n}} \frac{1}{\mathrm{y}_{\mathrm{i}}^{2}}\right]=-10 \log \left[\frac{1}{3}\left(\frac{1}{70^{2}}+\frac{1}{80^{2}}+\frac{1}{90^{2}}\right)\right]=18,07
$$

Table 1 - The Results Calculation of S / N ratio Based on Water Stability process

\begin{tabular}{|c|c|c|c|c|c|c|c|c|}
\hline \multirow{2}{*}{ Experiments } & \multicolumn{3}{|c|}{ Factors } & \multicolumn{2}{|c|}{ Experiment Results (WS values) Min } & \multirow{2}{*}{ Mean (WS) Min } & \multirow{2}{*}{ Ratio S/N (WS) Min } \\
\cline { 2 - 6 } & A & B & C & Rep 1 & Rep 2 & Rep 3 & & 18,07 \\
\hline 1 & 35 & 73 & 30 & 70 & 80 & 90 & 80 & 19,75 \\
\hline 2 & 35 & 74 & 60 & 82 & 75 & 92 & 83 & 19,75 \\
\hline 3 & 35 & 75 & 90 & 91 & 83 & 74 & 82,67 & 20,72 \\
\hline 4 & 37 & 73 & 60 & 81 & 90 & 75 & 82 & 19,14 \\
\hline 5 & 37 & 74 & 90 & 73 & 85 & 91 & 83 & 20,09 \\
\hline 6 & 37 & 75 & 30 & 90 & 89 & 75 & 84,67 & 20,59 \\
\hline 7 & 40 & 73 & 90 & 80 & 75 & 90 & 81,67 & 19,72 \\
\hline 8 & 40 & 74 & 30 & 74 & 82 & 91 & 82,33 & 18,9 \\
\hline 9 & 40 & 75 & 60 & 73 & 89 & 90 & 84 & \\
\hline
\end{tabular}


Table 2 - The average response of $\mathrm{S} / \mathrm{N}$ ratio Each Factor Based on the Water Stability

\begin{tabular}{|c|c|c|c|}
\hline & $A_{i}$ & $B_{i}$ & $C_{i}$ \\
\hline Level 1 & 19,19 & 19,79 & 19,29 \\
\hline Level 2 & 19,98 & 19,54 & 19,79 \\
\hline Level 3 & 19,73 & 19,58 & 19,82 \\
\hline Difference & 0,79 & 0,25 & 0,54 \\
\hline Rank & 1 & 3 & 2 \\
\hline
\end{tabular}

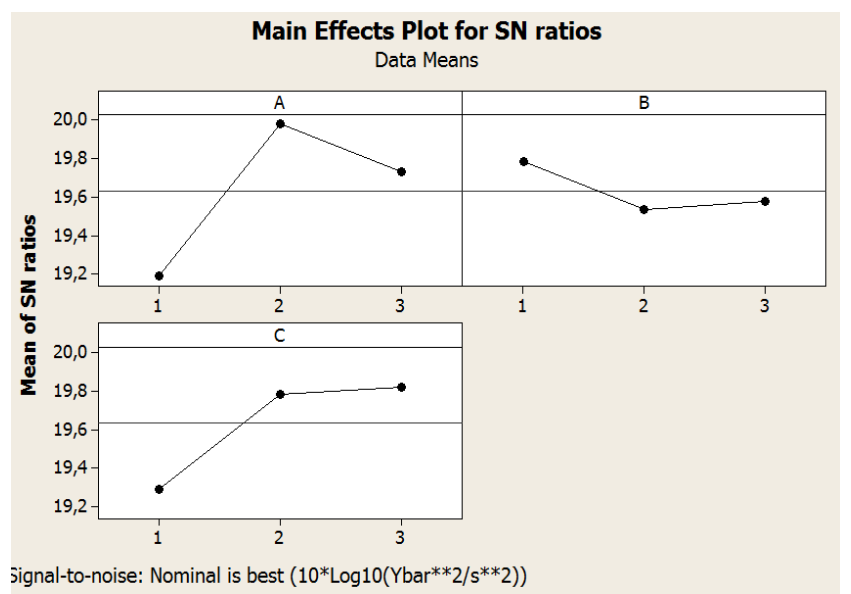

Figure 2 - The Factor Response Against The S / N Ratio On Water Stability Graph

Data processing. The incorporation factor as a starting error of a factor by the number of squares / sum-square (SS), the smallest of which is not significant factors combined with the sum of squared errors to total free degrees. (Sum square) the smallest of the factors that are not significant are:

Table 3 - Result of ANOVA for The Average Thickness On Quality of shrimp feed

\begin{tabular}{|c|c|c|c|}
\hline Sumber & V & SS & MS \\
\hline A & 2 & 11,3432 & 5,6716 \\
\hline B & 2 & 33,2654 & 16,6327 \\
\hline C & 2 & 9,22390 & 4,6195 \\
\hline Error & 14 & $171.885,942$ & 68,2575 \\
\hline Total & 20 & $171.939,745$ & 95,1813 \\
\hline
\end{tabular}

\section{DISCUSSION OF RESULTS}

Based on the results obtained in the previous analysis, where the standard used is Water as much (39\%), Temperature / Steam as much $\left(81^{\circ}\right)$, Machine Round Speed as much $(80 \mathrm{rpm})$. It is known that the combination of factors in the Water Stability process that affect the average and variation of quality on shrimp feed is the same, that is $37 \%$ water at level 2 (A2), Temperature / (Steam) as much as $73^{\circ} \mathrm{C}$ at level 1 (B1), and Engine speed of $90 \mathrm{rpm}$ at level 3 (C3).

From the calculation of confidence intervals at 95\% confidence level for Taguchi experiments were then compared with the experimental confirmation of the confidence interval for the confidence intervals are at Taguchi experiment. Thus the optimal combination of factors mentioned above proved to improve the quality of shrimp feed in the Water Stability process.

\section{CONCLUSION AND SUGGESTIONS}

In accordance with data processing and data analysis that has been shown in previous chapters, the conclusion that can be drawn from the results of this research are: 
The result of research from combination of optimum level and factor can improve on Water Stability (WS) process to the quality of shrimp feed with obtained from $37 \%$ Water Factor at level 2 (A2), Temperature / (Steam) as much as $73^{\circ} \mathrm{C}$ at level 1 (B1), and engine speed of $90 \mathrm{rpm}$ at level 3 (C3).

Propose improvements in shrimp feed with optimum value on Taguchi experiment with an average of 82.69 minutes and 33.56 minutes variability, whereas the experimental confirmation to the average and variability in the quality of shrimp feed was 82.27 minutes and 38.77 minute.

The research has been done to determine the combination of process variation so that the quality of Shrimp Feed in Water Stability process can be in accordance with the expected company.

The suggestions given are as follows:

- Taguchi method should be applied for determination of optimum combination of the level and the resulting factor for improving the quality of the shrimp feed on the Water Stability;

- Always maintain optimal conditions on the Water Stability as a way to maintain the quality of Shrimp Feed.

\section{REFERENCES}

1. Belavendram, N., 1995, Quality By Design: Taguchi Techniques for Industrial Experimentation, Prentice Hall, New York.

2. Kurniawan, C., Sugito, Yasin, H. 2014. Optimalisasi Jumlah Batu Bata Yang Pecah Menggunakan Desain Eksperimen Taguchi. Jurnal Gaussian, 3(2): 203 - 212 ISSN: 2339-2541

3. Ermawati, Hartati. 2014. Aplikasi Metode Taguchi Dalam Pengendalian Kualitas Produksi. Jurnal Teknosains, 8(2): 185-194

4. Fitria, Nana. Analisis Desain Eksperimen Taguchi dalam Optimasi Karakteristik Mutu. Unpublished Thesis.

5. http://lib.uin-malang.ac.id/file/skripsi/fullchapter/05510002.pdf (Accessed on May 13, 2012).

6. Gruvin.2005. Pengertian Kualitas. Surabaya: PT Berkah Media.

7. Hadi Saputro, I. Penentuan Parameter Permesinan pada Proses Pembuatan Diameter Luar Komponen Crank Sahft dengan Menggunakan Metode Taguchi. Unpublished Thesis.

8. http://eprints.undip.ac.id/2759/2/L2H_000_699.pdf. (Accessed on August 3, 2011).

9. Metasari, Nur. Design of Ekperiment. http://qualityengineering.wordpress.com/ tag/design-of-experiment/ (Accessed on March 13, 2011).

10. Anggoro, P.W. 2011. Analisis Setting Parameter Mesin Thermoforming. Jurnal Integra, $1(2): 207-217$

11. Ross, P.J. 2008. Taguchi Techniques for Quality Engineering, McGraw Hill Companies, Inc., Taiwan.

12. Soejanto, I., (2009), Desain Eksperimen Dengan Metode Taguchi. Yogyakarta: Graha IImu.

13. Taguchi, G., Chowdhury, S., Wu, Y. 2005. Taguchi's Quality Engineering Handbook. John Wiley \& Sons. Inc. Hoboken, New Jersey.

14. Tiska, Vanti 2016. Optimasi Proses Electroplating Terhadap Kualitas Chrome Dengan Menggunakan Metode Taguchi. Jurnal Teknik Industri, 1(1): 25-29.

15. Tanoto, Y. Y., Soepangkat, B. O., Wahjudi, A. 2014. Optimasi Multi Respon pada Proses Gurdi dengan Menggunakan Metode Taguchi-Grey. Jurnal Teknik Mesin, 16(1): 8-14. 